\title{
The effect of share exchange ratios on the wealth of participating firms involved in mergers
}

\author{
R.C. van den Honert ${ }^{\star}$
}

Department of Mathematical Statistics, University of Cape Town, Private Bag, Rondebosch, 7700

Republic of South Africa

\author{
G.D.I. Barr
}

Departments of Mathematical Statistics and Economics, University of Cape Town, Private Bag, Rondebosch, 7700 Republic of South Africa

\section{A.J. Galloway}

Graduate School of Business, University of Cape Town, Private Bag, Rondebosch, 7700 Republic of South Africa

\section{Accepted 19 October 1988}

\begin{abstract}
A mathematical model which relates the exchange ratio (the number of acquiring firm's shares issued for each target share) and the postmerger expected price earnings ratio of firms involved in mergers, is applied to 30 firms involved in recent share-exchange mergers on the Johannesburg Stock Exchange. It is found that about $70 \%$ of the mergers in the sample could be defined as rational, i.e. both shareholder parties gained in wealth. On the other hand, between $3 \%$ and $17 \%$ of the mergers led to a loss in wealth for both shareholder parties. Considering each party alone, between $70 \%$ and $80 \%$ of acquiring firms gained after merger, whilst for target firms $80 \%$ to $90 \%$ gained. It is also shown that the larger the target relative to the acquirer, the greater the share of the merger gains accumulating to the target.
\end{abstract}

\begin{abstract}
'n Wiskundige model wat die verhouding tussen die wisselverhouding (die hoeveelheid aandele van die oornemende maatskappy wat uitgegee word vir elke aandeel van die oorgenome maatskappy) en die nasamesmelting verwagte prysverdienste-verhouding van maatskappye wat in samesmeltings betrokke is, is op 30 maatskappye wat in onlangse samesmeltings op die Johannesburgse Effektebeurs betrokke was, toegepas. Daar word bevind dat ongeveer $70 \%$ van die samesmeltings in die monster as rasioneel beskryf kon word, d.w.s. dat albei aandeelhouersgroepe 'n wins gemaak het. Aan die ander kant, het tussen $3 \%$ en $17 \%$ van die samesmeltings tot 'n verlies vir albei aandeelhouersgroepe gelei. As elke aandeelhouersgroep alleen in ag geneem word, het tussen $70 \%$ en $\mathbf{8 0} \%$ van oornemende maatskappye 'n wins gemaak, maar tussen $80 \%$ en $90 \%$ van dic oorgenome maatskappye het 'n wins gemaak. Daar is ook bewys dat hoe groter die oorgenome maatskappy is teenoor die oornemende maatskappy, hoe groter is die porsie van die samesmeltingwins wat die oorgenome maatskappy toekom.
\end{abstract}

*To whom correspondence should be addressed

\section{Introduction}

A merger between two firms frequently involves the exchange of a new issue of acquiring firm's shares for the original shares of the target firm. The important parameter in such a share exchange is the share exchange ratio, defined as the number of acquiring firm's shares issued for each target share. This exchange ratio is predetermined by the managements of the two participating firms and implicitly determines the wealth premium (positive, zero or negative) paid by the acquiring firm's shareholders to the target firm's shareholders. Naturally, the acquiring firm's management strives for a low exchange ratio, whilst the target firm's management strives for a high exchange ratio. Thus each party can experience an increase, decrease or no change to its wealth, depending on the exchange ratio and the value attached to the merged entity by the market.

This paper considers an application of an exchange ratio determination model (similar in concept to one developed by Larsen \& Gonedes (1969)) to recent mergers on the Johannesburg Stock Exchange (JSE). This model evaluates the premium paid by an acquirer to a target using the share exchange ratio, and thus allows the effects on the shareholders' wealth positions to be considered for mergers that have been financed exclusively by ordinary share exchanges.

The approach allows one to classify mergers according to the rationality of the participants and to form some assessment of the gains or losses accruing to the participating parties. An empirical study is undertaken which assesses participant rationality and associated wealth change for share exchange schemes undertaken on the JSE from February 1972 to April 1987.

\section{The exchange ratio determination model}

Consider an acquiring firm $\mathrm{A}$ and a target firm $\mathrm{B}$. The premerger wealth positions per share of the respective shareholders are:

$W_{A}=\left(P E_{A}\right)\left(E_{A} / S_{A}\right)=P_{A}$

$W_{B}=\left(P E_{B}\right)\left(E_{B} / S_{B}\right)=P_{B}$

where $W_{A}$ and $W_{B}=$ current wealth position of the holder of one share of firms $A$ and $B ; P_{A}$ and $P_{B}=$ premerger market price per share of firms $A$ and $B$; 
$P E_{A}$ and $P E_{B}=$ pre-merger price earnings ratios of firms $A$ and $B ; E_{A}$ and $E_{B}=$ total earnings of firms $A$ and $B$; and $S_{A}$ and $S_{B}=$ total outstanding number of shares of firms $A$ and $B$.

We assume the wealth of a shareholder is simply the market value of his holding and thus the expected postmerger wealth position of a shareholder in the new entity $A B$ is

$W_{A B}=\left(P E_{A B}\right)\left[\left(E_{A}+E_{B}\right) /\left(S_{A}+(E R)\left(S_{B}\right)\right)\right]$

where $P E_{A B}=$ the expected post-merger $P E$ ratio of firm $\mathrm{AB} ; \mathrm{ER}=$ common stock exchange ratio (number of acquirer shares per target share); and $\mathrm{W}_{\mathrm{AB}}=$ postmerger wealth position of holder of one share in the combined entity.

There are two important points to note:

1. It is assumed that the acquirer issues a number of new shares to finance the merger, and these are swopped for the target firm's shares. This number depends on the exchange ratio agreed upon by the target firm and the acquiring firm. Thus the post-merger number of shares outstanding is the sum of the acquirer's premerger number of shares outstanding and the number of new acquiring firm's shares issued. That is,

$S_{A B}=S_{A}+(E R)\left(S_{B}\right)$

where $S_{A B}=$ the number of outstanding shares of the merged firm AB.

2. The post-merger earnings of the combined entity is assumed to be the sum of the pre-merger earnings of the separate firms. Thus it is assumed that over the merger period there is no synergy effect.

\section{Analysis of wealth changes for target and acquirer shareholders}

For the acquirer shareholders to experience a wealth increase

$\mathbf{W}_{\mathbf{A B}} \geqslant \mathbf{W}_{\mathbf{A}}$

or equivalently,

$\mathbf{P}_{\mathbf{A B}} \geqslant \mathbf{P}_{\mathbf{A}}$

Similarly, for the target shareholders to experience a wealth increase,

$W_{A B} \geqslant(1 / E R)\left(W_{B}\right)$ or

$P_{A B} \geqslant(1 / E R)\left(P_{B}\right)$

The maximum exchange ratio acceptable to acquirer shareholders is found by substituting (3) and (1) into (4) to yield:

$$
\begin{aligned}
& \left(P E_{A B}\right)\left[\left(E_{A}+E_{B}\right) /\right. \\
& \left.\left(S_{A}+\left(E R_{A}\right)\left(S_{B}\right)\right)\right] \geqslant\left(P E_{A}\right)\left(E_{A} / S_{A}\right) .
\end{aligned}
$$

Thus,

$E R_{A} \leqslant \frac{\left(P E_{A B}\right)\left(E_{A}+E_{B}\right)-\left(P E_{A}\right)\left(E_{A}\right)}{\left(P E_{A}\right)\left(E_{A}\right)\left(S_{B} / S_{A}\right)}$

which can be expressed as

$$
\begin{aligned}
& E R_{A} \leqslant\left(S_{A} / S_{B}\right)\left[-1+\left(\left(E_{A}+E_{B}\right)\left(P E_{A B}\right) /\right.\right. \\
& \left.\left.\left(P_{A}\right)\left(S_{A}\right)\right)\right]
\end{aligned}
$$

where $\left(P E_{A}\right)\left(E_{A}\right)=\left(P_{A}\right)\left(S_{A}\right)$.

This is an upper limit (from the acquirer's point of view) on the linear relationship between the exchange ratio and the post-merger expected price earnings ratio.

Similarly, the minimum exchange ratio acceptable to target shareholders is found by substituting (3) and (2) into (5). That is:

$$
\begin{aligned}
& \left(P E_{A B}\right)\left[\left(E_{A}+E_{B}\right) /\left(S_{A}+\left(E R_{B}\right)\left(S_{B}\right)\right)\right] \\
& \geqslant\left(1 / E R_{B}\right)\left(P E_{B}\right)\left(E_{B}\right) / S_{B} .
\end{aligned}
$$

This yields

$$
E R_{B} \geqslant \frac{\left(P E_{B}\right)\left(E_{B} / S_{B}\right)\left(S_{A}\right)}{\left(P E_{A B}\right)\left(E_{A}+E_{B}\right)-\left(P E_{B}\right)\left(E_{B}\right)}
$$

which can be expressed as

$$
E R_{B} \geqslant \frac{\left(P_{B}\right)\left(S_{A}\right)}{\left(P E_{A B}\right)\left(E_{A}+E_{B}\right)-\left(P_{B}\right)\left(S_{B}\right)}
$$

where $\left(P E_{B}\right)\left(E_{B}\right)=\left(P_{B}\right)\left(S_{B}\right)$.

This is a lower limit (from the target shareholder's point of view) in the non-linear relationship between the exchange ratio and the post-merger expected price earnings ratio. It can be seen that the exchange ratio varies inversely with the post-merger expected price earnings ratio.

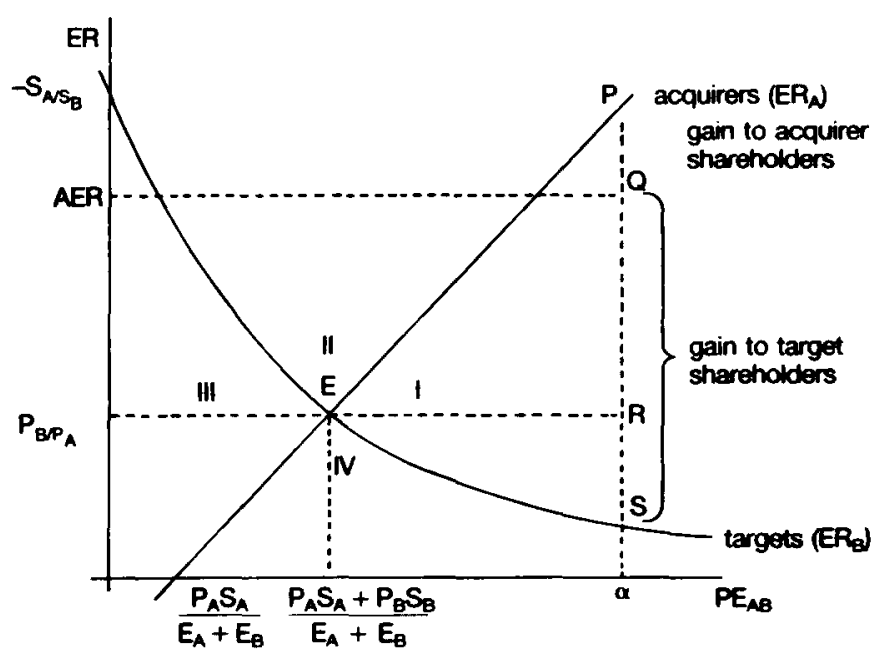

Figure 1 The ralationship between the exchange ratio and the expected post-merger price earnings ratio, for acquiring and target firms 
The equalities in equations (6) and (7) above represent positions where the shareholders of the acquiring and target firms have neither gained nor lost wealth due to merger. These can be seen in Figure 1.

Note that for completeness the intercepts with the two axes are indicated. In practice, however, it is extremely unlikely that either of these situations will apply i.e. post-merger price earnings ratio $=0$ or exchange ratio $=0$. The latter case indicates that the target shareholders receive no shares at all for their shares at merger.

Of importance is the intersection of the two curves (point E). At this point both sets of shareholders neither gain nor lose from merger. That is

$\mathrm{ER}_{\mathrm{A}}=\mathrm{ER}_{\mathrm{B}}=\mathbf{P}_{\mathrm{B}} / \mathrm{P}_{\mathrm{A}}$

The wealth position of the acquirer shareholders remains unchanged along line $\mathrm{ER}_{\mathrm{A}}$, so

$\mathbf{P}_{\mathrm{AB}}=\mathbf{P}_{\mathbf{A}}$

Now

$P_{A B}=\left(P E_{A B}\right)\left(E P S_{A B}\right)$

and

$\mathrm{EPS}_{\mathrm{AB}}=\left(\mathrm{E}_{\mathrm{A}}+\mathrm{E}_{\mathrm{B}}\right) /\left[\mathrm{S}_{\mathrm{A}}+\left(\mathrm{S}_{\mathrm{B}}\right)(\mathrm{ER})\right]$

Substituting (11) into (10) yields

$P E_{A B}=\frac{P_{A B}\left[S_{A}+\left(S_{B}\right)(E R)\right]}{E_{A}+E_{B}}$

Now from (9) and (8) the post-merger expected price earnings ratio at point $E$ is

$P_{A B}=\frac{P_{A}\left[S_{A}+\left(S_{B}\right)\left(P_{B} / P_{A}\right)\right]}{E_{A}+E_{B}}=\frac{\left(P_{A}\right)\left(S_{A}\right)+\left(P_{B}\right)\left(S_{B}\right)}{E_{A}+E_{B}}$

The model has been derived in a pre-merger sense where a post-merger price earnings ratio is anticipated by both acquiring and target firm's management. A feasible set of exchange ratios can thus be mapped out which will result in neither set of shareholders losing wealth from the merger. This ratio will determine the split of the realized post-merger gains or losses between the acquirer and target firm's shareholders. Since the post-merger price earnings ratio depends implicitly on the post-merger market price per share of the combined firm the actual exchange ratio settled upon depends on the value the market attaches to the post-merger combined entity. Thus the synergy gains from merger resulting in a realized post-merger price earnings ratio will be split between the acquiring and target firm's shareholders depending on the actual exchange ratio (AER) settled upon. In Figure 1 line segment PS represents the synergy gains resulting from merger, line segment QS represents the gain, or premium, to the target shareholders and line segment PQ represents the gain to the acquirer shareholders. In a post-merger sense the model can be used to evaluate the worth attached to the merger by the market and hence whether the merger was a positive net present value decision, whether the managements set an exchange ratio which resulted in a rational merger and how the gains (if any) were split between the two sets of shareholders.

From equations (6) and (7) it will readily be seen that the acquiring firm's shareholders gain in wealth if the exchange ratio/post-merger price earnings ratio combination falls into quadrants I and IV of Figure 1, and target firms shareholders gain in wealth if it falls into quadrants I and II.

Thus a merger can be termed 'rational' if the combination of realized post-merger price earnings ratio and actual exchange ratio settled upon falls in quadrant I of Figure 1.

Table 1 shows the situation represented by the four quadrants in Figure 1.

\section{Premium accruing to the target and acquirer shareholders}

The apparent premium paid to the target shareholders for a particular realized post-merger price earnings ratio is

$$
\begin{aligned}
\text { Premium }_{B} \% & =\left(\text { AER }-\left(\mathbf{P}_{B}\right) /\left(\mathbf{P}_{A}\right)\right) /\left(\mathbf{P}_{B} / \mathbf{P}_{A}\right) \\
& =\left[\left((\text { AER })\left(\mathbf{P}_{A}\right)-\mathbf{P}_{B}\right) / P_{B}\right] \times 100 \ldots
\end{aligned}
$$

where AER is the actual exchange ratio used in the merger.

This corresponds to line segment QR in Figure 1. But this uses pre-merger market prices of the two participating firms and ignores any synergy gains that may occur and reflect in the postmerger price. Part of this synergy gain will be attributable to the target shareholders as they hold acquirer shares after the merger. Thus the effective premium for a particular realized post-merger price earnings ratio is actually represented by line segment QS in Figure 1. Expressed as a percentage this premium is

Premium $_{B} \%=\frac{\text { AER }-E_{B}}{E_{B}} \times 100$

Table 1 Shareholders wealth changes for the four quadrants of Figure 1

\begin{tabular}{ccc}
\hline Quadrant & $\begin{array}{c}\text { Target shareholder's } \\
\text { wealth change }\end{array}$ & $\begin{array}{c}\text { Target shareholder's } \\
\text { wealth change }\end{array}$ \\
\hline I & + & + \\
II & - & + \\
III & - & - \\
IV & + & - \\
\hline
\end{tabular}

+ implies a gain in wealth; - implies a loss in wealth 
since points on line $\mathrm{ER}_{\mathrm{B}}$ represent no change to the wealth position of the target shareholders. From equation (5) it is clear that the following equality holds along line $\mathrm{ER}_{\mathrm{B}}$ :

$W_{B}=\left(W_{A B}\right)\left(E R_{B}\right)$ or

$P_{B}=\left(P_{A B}\right)\left(E R_{B}\right)$

and thus $\mathrm{ER}_{\mathrm{B}}=\mathrm{P}_{\mathrm{B}} / \mathrm{P}_{\mathrm{AB}}$.

Substituting this into (14) yields

$$
\begin{aligned}
\text { Premium }_{B} \% & =\frac{A E R-\left(P_{B} / P_{A B}\right)}{\left(P_{B} / P_{A B}\right)} \times 100 \\
& =\frac{(A E R)\left(P_{A B}\right)-P_{B}}{P_{B}} \times 100
\end{aligned}
$$

where $P_{A B}=$ post-merger market price of combined firm $A B ; P_{B}=$ pre-merger price of firm $B$; and AER = actual exchange ratio.

Note that equation (16) reduces to equation (13) if the post-merger market price of the combined entity $A B$ is the same as the pre-merger market price of the acquiring firm A.

The premium to the acquirer shareholders is represented by line segment $P Q$ in Figure 1 . This can be expressed as

$$
\text { Premium }_{\mathbf{A}} \%=\frac{\mathbf{P}_{\mathbf{A B}}-\mathbf{P}_{\mathbf{A}}}{\mathbf{P}_{\mathbf{A}}} \times 100 \ldots \ldots \ldots \ldots
$$

\section{Comparison with the cumulative average residual framework}

The model as laid out above has several limitations. Firstly, unlike the cumulative average residual method proposed by Fama, Fisher, Jensen \& Roll (1969), this methodology does not adjust for market movements. Thus effects observed around the time of the merger announcement could have been due to market-wide movements and not just to the market's reaction to the merger announcement. However this problem can be largely overcome by choosing a sample of mergers which covers one or more complete market cycles. The positive bias of mergers occurring on the upswings will be offset to a certain extent by the negative bias of mergers occurring on the downswings. This study on the Johannesburg Stock Exchange stretches from February 1972 to April 1987, a period covering about four major market cycles. Secondly, the model assumes the market has the same information as the managements of the merging firms, and so can accurately assess the merger. Management, however, may be in possession of relevant information not available to the market. This may have some effect on earnings in the short term, but these additional earnings are not discounted by the market in its evaluation. Thirdly, the model only considers changes in the wealth of the shareholders of the participating firms from a point just after the merger. This does not allow an assessment of the merger over a longer time frame. However if the market is assumed to be efficient, all changes in share prices should take place instantaneously, and so this problem is not considered to be serious.

Finally, this model can only be applied to mergers financed by ordinary share exchanges, and thus excludes all those mergers financed by means of cash or a choice of cash or shares.

\section{Empirical analysis}

In order to apply the above ideas we examined a set of $\mathbf{3 0}$ mergers on the Johannesburg Stock Exchange (JSE) over the period February 1972 to April 1987. These were identified from the JSE Monthly Bulletin by invoking the following criteria for sample selection:

a. Financing had to be by means of an exchange of ordinary shares. That is, the acquiring firm issued new shares with which to acquire those of the target. This requirement was the major factor in limiting the sample size, as most mergers during this period were financed either by cash or by a choice of cash or acquirer's shares.

b. The simple form of the model presented above only considers an acquisition of a single target firm. Without complex modification, mergers involving two or more target firms at the same time cannot be handled, and thus were excluded from the sample.

c. The acquiring firm must not have engaged in any other merger or acquisition, or had changes to its issued ordinary shares in the period six months before until two months after the merger announcement. In this way the effect of the single merger can be determined, without confounding effects of other mergers.

d. The frequency of trading of the acquiring and target firm's shares had to exceed an average of ten deals per month. This was to ensure market efficiency in the shares concerned. Certain event studies have used a minimum average annual trading volume (say 250000 shares traded per annum on average) to ensure market efficiency, but this is oversimplified, as this number could arise from a single deal in the year on a thinly traded market (such as the JSE) where a large market capitalization share is involved.

A complete list of the 30 mergers can be found in Appendix A.

\section{Data collection and methodology}

In this study the model will be used ex post to evaluate $\mathbf{3 0}$ recent South African mergers of listed companies.

As mentioned previously, a 'rational' merger was considered to be one where there are wealth gains accruing to both the acquiring and target firm's shareholders.

In a market where the semi-strong form of the efficient market hypothesis holds, any new publicly available information is immediately capitalized into the share prices. In the case of a merger new information appears at more than one particular point in time. The first public announcement of the proposed merger is usually taken as the relevant date, but the JSE has been 
shown to start capitalizing merger benefits before this date (Affleck-Graves, Flach and Jacobson (1988), Bhana (1987), van den Honert, Barr, Affleck-Graves and Smale (1988)). This could be due to the market perceiving a probability of an impending merger based on information contained in the firm's financial statements and from other sources. As there is not complete certainty about the merger only a proportion of the gains to be had from merger are capitalized before the announcement. On the announcement date almost all the uncertainty is removed and the major capitalization takes place at this time. Preannouncement gains could also be due to information leakages about the merger and speculation (Bhana (1987)). For the model to assess the gains or losses to investors due to merger, their pre-merger wealth positions have to be determined. But due to the market capitalizing a proportion of the merger gains before the actual first public announcement, share prices from a period sufficiently far in advance of the announcement date should be used to avoid these effects. All the studies on the wealth effects of mergers on the South African market (Affleck-Graves, Flach and Jacobson (1988), van den Honert, Barr, Affleck-Graves and Smale (1988), Bhana (1987)) indicate that these effects start to occur about three months before the first public announcement, thus share prices in the three months preceding the three-month period prior to the announcement were used to determine the pre-merger wealth positions of the acquiring and target firm's shareholders.

As this study considers changes in wealth effects due to the merger, all results will be calculated for three dates: the announcement month, and the two months thereafter.

Inequalities (6) and (7) of the model relate the exchange ratio with the expected post-merger price earnings ratio. The constituent terms of these equations form the data required for the model.

1. The pre-merger prices $\left(P_{A}\right.$ and $\left.P_{B}\right)$. The month of the merger announcement will be termed month 0 . In order to avoid pre-announcement effects, averages of the high and low monthly prices for months $-6,-5$ and -4 were taken to determine the pre-merger wealth positions of the respective shareholders.

2. The pre-merger number of issued shares $\left(S_{A}\right.$ and $\left.S_{B}\right)$. The shares in issue at months $-6,-5$ and -4 (in all cases equal to the number in issue at the announcement date) were found in the JSE monthly bulletin.

3. Pre-merger earnings $\left(E_{A}\right.$ and $\left.E_{B}\right)$. The earnings figures in the firm's annual financial statements most recent to the merger were taken.

4. Post-merger price earnings ratio $\left(\mathrm{PE}_{\mathrm{AB}}\right)$. Equation (3) can be rearranged to yield

$$
P E_{A B}=\frac{P_{A B}}{\left(E_{A}+E_{B}\right) /\left[S_{A}+\left(S_{B}\right)(A E R)\right]}
$$

This equation can be used to obtain the post-merger price earnings ratio for months 0,1 and 2 . Here $P_{A B}$ w

prices of the combined entity for each of the three months under consideration. The objective of considering months beyond that of the merger announcement is to show up any reassessment of the merger by the market.

5. Actual exchange ratios $\left(E R_{A}\right.$ and $\left.E R_{B}\right)$ are an integral part of the merger documentation and can be found in the JSE monthly bulletins.

If the inequalities (6) and (7) both hold then the merger can be considered 'rational'. If both do not hold then both shareholder parties are losing from the merger and if only one of the inequalities hold then only that shareholder party is gaining from merger. By substituting the data described above into the two inequalities it can be ascertained into which quadrant of Figure 1 the merger falls, and then the two shareholder parties'

\section{Hypothesis tests}

Statistical hypothesis tests were performed on the sample of 30 mergers to test the following hypotheses:

a. The merger's realized post-merger price earnings ratio exceeds its minimum acceptable expected postmerger price earnings ratio, i.e. both parties experience a wealth gain;

b. the merger's realized post-merger price earnings ratio exceeds its minimum acceptable expected postmerger price earnings ratio for acquirer's only, i.e. acquirer shareholders gain (irrespective of the effect on the target);

c. the merger's realized post-merger price earnings ratio exceeds its minimum acceptable expected postmerger price earnings ratio for targets only, i.e. target shareholders gain (irrespective of the effect on the acquirer).

It is furthermore hypothesized that the larger the target (in terms of market capitalization) relative to the acquirer, the more the actual exchange ratio will be set in favour of the target. Thus the target will receive a larger share of the merger gains. Thus the effect of relative sizes of the target and the acquirer and their resulting bargaining powers was examined. This was accomplished by fitting a simple linear regression line to the data of the rational mergers only. The ratio of the market capitalizations of the target and acquiring firms was used as independent variable and the ratio of rand gains received by the target to the total rand gains of the merger was used as the dependent variable. Total rand gains (TRG) can be expressed as

$T R G=\left(S_{A}\right)\left(P_{A B}-P_{A}\right)+\left(S_{B}\right)\left((A E R)\left(P_{A B}\right)-P_{B}\right)$

comprising,

$\left(S_{A}\right)\left(P_{A B}-P_{A}\right)=$ gains to acquirer

. $\left(\mathrm{S}_{\mathrm{B}}\right)\left((\mathrm{AER})\left(\mathrm{P}_{\mathrm{AB}}\right)-\mathrm{P}_{\mathrm{B}}\right)=$ gains to target

Thus the ratio of rand gains received by the target to the total rand gains of the merger (RGR) is 
$\mathbf{R G R}=\frac{\left(\mathrm{S}_{\mathrm{B}}\right)\left((\mathrm{AER}) \mathrm{P}_{\mathrm{AB}}-\mathbf{P}_{\mathrm{B}}\right)}{\mathrm{TRG}}$

The degree of linear fit between $R G R$ and relative market capitalization was considered by estimating the regression equation

$R G R=\alpha+\beta\left(M_{B} / M_{A}\right)$

where $M C_{B}$ and $M C_{A}$ are the market capitalizations of the target and acquirer respectively.

A high degree of explanation of $\mathrm{RGR}$ by $\mathrm{MC}_{\mathrm{B}} / \mathrm{MC}_{\mathrm{A}}$ implies that relative size of the two firms may be taken to be a proxy for the bargaining power the two firms take to the negotiating table.

\section{Empirical results}

The number of mergers ( 30 in all) falling into each of the four quadrants of the model for the merger announcement month and the two subsequent months are shown in Figure 2.

The numbers in brackets are used to indicate announcement month $(0)$ as well as the two months thereafter, (1) and (2). The percentages represent the number of mergers relative to the total sample size.

At the time of the announcement $73 \%$ of the mergers were considered rational by the market, demonstrating the market's belief that synergistic gains would be realized. This view is maintained over the first month after the announcement, but during the next month the market became more pessimistic about the mergers, with $67 \%$ of the mergers leaving the wealth position of both shareholder parties improved.

Quadrant II represents mergers in which only the target firm's shareholders gained, whilst the acquiring firm's shareholders lost wealth. The percentage of the mergers in this situation was $17 \%$ at the announcement date, but decreased to $13 \%$ two months later. These mergers appear to shift to Quadrant III of Figure 2, as the proportion of mergers increases steadily from $3 \%$ at announcement to $17 \%$ two months later. These are the

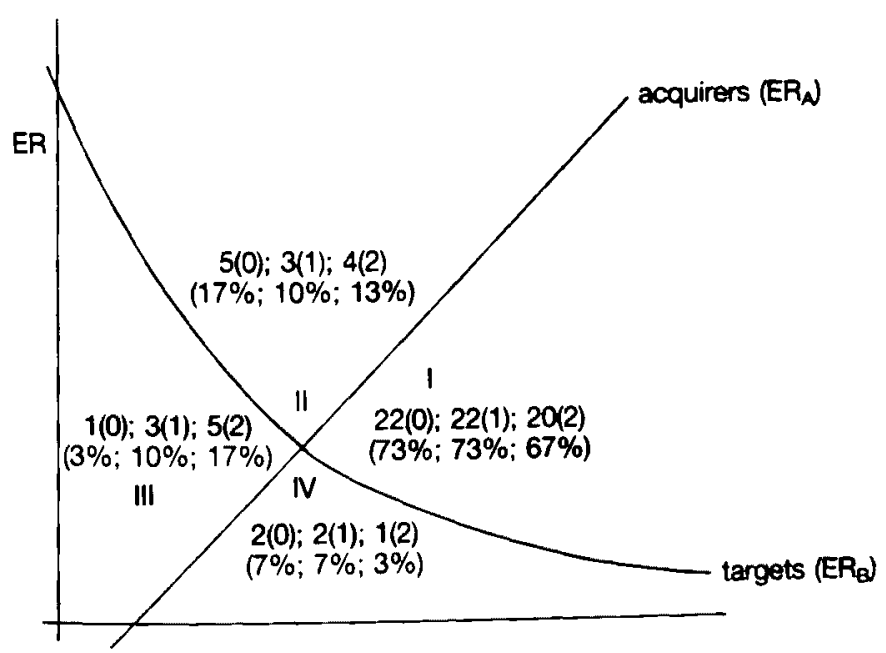

Figure 2 The distribution of 30 mergers into the four quadrants of the model mergers that are defined as totally irrational, i.e. both shareholder parties lose wealth. This result is in keeping with the South African merger studies of AffleckGraves, Flach and Jacobson (1988) and van den Honert, Barr, Affleck-Graves and Smale (1988) both using residual analysis, which showed that, on average, acquirers lost wealth in the medium and longer term, whilst targets had accumulated all their wealth gains by the merger announcement date.

The proportion of mergers falling in Quadrant IV was very small over the whole period considered, which supports the results of the previous studies in that acquiring firm's shareholders seldom gain whilst the target loses wealth. Thus it can be hypothesized that the takeover market is competitive, and thus premiums paid by the acquirers are generally higher than those received by the acquirers. In general then, it can be seen that the acquirer and target manangements are largely rational in behaviour, striving for wealth gains for both sets of shareholders. At the announcement date the market over-reacts but adjusts for this optimism over the following two months.

Consider now the number of mergers showing a wealth loss to one party, with the effect on the other being ignored. In the case of acquirers this correspond to a position in Quadrants II and III. At announcement, $20 \%$ of mergers resulted in a wealth loss to the acquirer's shareholders and this increases to $30 \%$ two months later. An explanation for this is that the market, basing its assessment on all publicly available information, is overoptimistic. As more information concerning the merger becomes available the market reacts negatively, realizing that the acquirer management is operating in its' own personal interests rather than the best interests of the firm's shareholders.

The mergers resulting in wealth losses to target firms' shareholders, irrespective of the outcome to acquirers shareholders, fall in Quadarants III and IV of Figure 2. At announcement $10 \%$ of targets had experienced wealth losses, and this increases to $20 \%$ two months later. This increasing proportion of targets is to be expected, since only share-financed mergers have been considered, and so the premium received by the target shareholders is proportional to the acquirer's share price. If the acquirer's share price decreases (as has already been shown) the wealth position of the target shareholders will also be prejudiced. As a result the more marginal rational mergers will shift from a wealth gain to a loss position. This behaviour is evidenced by the move of mergers from Quadrants I, II and IV to Quadrant III. Target management may, however, support a merger that leads to shareholder losses, due to the personal gains (in the form of 'golden handshakes') that may be made by the management team. As has been suggested by Jensen and Ruback (1983) there is a market for corporate control where the only important participants are the respective management teams. Shareholders, due to their remoteness from the firm, have little significant influence over the behaviour of management. This therefore allows 'personal maximisation' behaviour on the part of target managements. 
An argument that has been put forward to explain why acquirers might undertake mergers that lead to wealth losses for their shareholders has been put forward by Varaiya and Ferris (1987). Due to the difficulty in the valuation of a target firm, various acquirers in the market will arrive at different results. Some will overestimate the value of the target firm, some will reach a fair value, and others will underestimate the value. In a competitive takeover market the target performing in the best interests of its shareholders will look for the best deal, and so there will be a bias towards mergers taking place in which the acquirers have overvalued the target. Although the market may not initially realize this based on information at its disposal, it will do so in time, and the market price of the acquiring firm's shares will experience a period of negative returns as the market reassesses the merger. Thus the high premium paid by the acquiring firm only leads to gains for the target firm's shareholders.

The hypothesis that the merger was rational, i.e. both parties experience a wealth gain, was tested by comparing the merger's realized post-merger price earnings ratio and its minimum acceptable expected post-merger price earnings ratio.

Statistically speaking, this was accomplished by using a one sample $t$-test, and performed for each of the three months under consideration. The results are presented in Table 2.

For all three months the alternate hypothesis of wealth gains to both parties is accepted, at least at the $10 \%$ level. It will be noted that the significance level decreases in the second month after the announcement, a result which is consistent with the decrease in the number of rational mergers in that month (see Figure 2).

The hypotheses that the acquirers gained (irrespective of the effect on the target) and that the targets gained (irrespective of the effect on the acquirers) were tested in an identical way. The results are shown in Tables 3 and 4 respectively.

Both of the above tests indicate a significant wealth gain for the party concerned in the announcement month and in the two subsequent months. Note that the significance level of target firms is much higher than that of the acquiring firms in all months considered. This is indicative of the large premium paid by the acquiring firms to the target firms.

Table 2 Hypothesis test of merger rationality for announcement month and two subsequent months

\begin{tabular}{lccc}
\hline & \multicolumn{3}{c}{ Months } \\
\cline { 2 - 4 } & 0 & 1 & 2 \\
\hline Mean $P_{E}$ gain & 1,1 & 0,9 & 0,6 \\
Standard deviation of $P_{E}$ gain & 2,69 & 2,33 & 2,27 \\
Sample size & 30 & 30 & 30 \\
$t$-statistic & $2,24^{* *}$ & $2,12^{* *}$ & $1,45^{*}$ \\
\hline
\end{tabular}

* significant at the $10 \%$ level; ** significant at the $5 \%$ level
It was furthermore hypothesized that the larger the target is relative to the acquirer, the more the actual exchange ratio will be set in favour of the target, giving the target a larger share of the merger gains. That is, a relatively small target must be prepared to sacrifice gains for the security and resources of the merger. This was tested on the rational mergers only by means of a simple linear regression, using the market capitalization ratio of target to acquirer as independent variable and relative rand gain as dependent variable. The results are presented in Table 5.

The correlations in all 3 months are high; in fact they

Table 3 Hypothesis test of merger gains for acquirers (irrespective of effect on targets) for announcement month and two subsequent months

\begin{tabular}{lccc}
\hline & \multicolumn{3}{c}{ Month } \\
\cline { 2 - 4 } & 0 & 1 & 2 \\
\hline Mean P & & & \multicolumn{3}{c}{ gain } \\
Standard deviation of $P_{E}$ gain & 2,76 & 2,22 & 2,54 \\
Sample size & 30 & 30 & 30 \\
$t$-statistic & $2,78^{* * *}$ & $2,72^{* *}$ & $1,94^{*}$ \\
\hline
\end{tabular}

* significant at the $5 \%$ level; ${ }^{* *}$ significant at the $1 \%$ level

*** significant at the $0,5 \%$ level

Table 4 Hypothesis test of merger gains for targets (irrespective of effect on acquirers) for announcement month and two subsequent months

\begin{tabular}{lccc} 
& \multicolumn{3}{c}{ Month } \\
\cline { 2 - 4 } & 0 & 1 & 2 \\
\hline Mean $P_{E}$ gain & 2,4 & 2,1 & 1,9 \\
Standard deviation of $P_{E}$ gain & 3,90 & 3,24 & 2,96 \\
Sample size & 30 & 30 & 30 \\
$t$-statistic & $3,37^{* *}$ & $3,55^{*}$ & $3,51^{*}$ \\
\hline
\end{tabular}

* significant at the $0,1 \%$ level; ${ }^{* *}$ significant at the $0,25 \%$ level

Table 5 Results of linear regression of market capitalization ratio on rand gains to the target

\begin{tabular}{cccc}
\hline Month & \multicolumn{2}{c}{$\begin{array}{c}\text { Regression equation (18) } \\
(t \text {-values in brackets })\end{array}$} & $\mathbf{R}^{2}$ \\
\hline \multicolumn{4}{c}{$\boldsymbol{\alpha}$} \\
\hline 0 & $0,2250(4,26)$ & $0,3059(4,93)$ & 0,5483 \\
1 & $0,2535(3,76)$ & $0,3061(3,71)$ & 0,4072 \\
2 & $0,1330(2,09)$ & $0,5988(4,41)$ & 0,5192 \\
\hline
\end{tabular}


are all significant at the $0,1 \%$ level. This indicates that the larger a target is relative to the acquirer, the larger its share of the total rand gains.

\section{Conclusions}

The following features emerge from the empirical results presented above:

From the date of merger announcement until two months later between $67 \%$ and $73 \%$ of the mergers in the sample were rational, i.e. both shareholder parties gained in wealth. On the other hand, in between only $3 \%$ and $17 \%$ of the mergers both shareholder parties lost wealth. In the balance of cases only one party gained, whilst the other party lost wealth. This indicates that in the short term (up to two months after the merger) management of acquiring and target firms have largely been acting to maximize the value of their shareholders wealth.

Considering each party alone, between $70 \%$ and $80 \%$ of the acquiring firms gained in the two months after the merger announcement, whilst in the case of the target firms these proportions were between $80 \%$ and $90 \%$. Thus target firms' shareholders are more likely to gain from mergers than are the acquiring firms' shareholders.

Furthermore, it was shown that the larger the target is relative to the acquirer (in terms of market capitilization), the greater the share of the merger gains accumulating to the target.

\section{Acknowlodgements}

Financial assistance rendered by the Human Sciences Research Council towards the cost of this research is hereby acknowledged. Opinions expressed or conclusions arrived at are those of the authors and not necessarily those of the HRSC.

\section{References}

Affleck-Graves, J.F.. Flach. T.P. \& Jacobson, A.S. 1988. The effect of merger announcements on the share prices of the acquired and acquiring companies. S. Afr. J. Bus. Mgmt.. vol. 19, 147-154.

Bhana, N. 1987. Take-over announcements and insider trading activity on the Johannesburg Stock Exchange. S. Afr. J. fus. Mgmt, Vol. 18. 198-208.

Fama, E.F., Fisher, L.. Jensen, M. \& Roll. R. 1969. The adjustment of stock prices to new information. Internat. Ec. Rev., February 1969, 1-21.

Jensen, M.C. \& Ruback. R.S. 1983. The market for corporate control: The evidence. J. Fin. Econ., Vol. 11. 5-\$0.

Larsen, K.D. \& Gonedes, N.J. 1969. Business combinations: An exchange ratio determination model. The Acc. Rev., October 1969, 720-728.

Van den Honert, R.C., Barr, G.D.I., Affleck-Graves, J.F. \& Smale, G. 1988. Merger announcements and share price return - the role of the relationship between acquiring and target firms. S. Afr. J. Bus. Mgmt., Vol. 19, 1-10.

Varaiya, N.P. \& Ferris, K.R. 1987. Overpaying in corporate takeovers: The winner's curse. Fin. Analysts J., May-June 1987, 64-70.

Appendix A Merger data

\begin{tabular}{|c|c|c|c|c|}
\hline No & Acquirer name & Target name & $\begin{array}{c}\text { Date } \\
\text { announced }\end{array}$ & $\begin{array}{c}\text { Date } \\
\text { delisted }\end{array}$ \\
\hline 1 & Welkom & Free-State Saaiplaas & $12 / 80$ & $08 / 81$ \\
\hline 2 & U.C. Investments & Sentrust Beperk & $08 / 83$ & $11 / 83$ \\
\hline 3 & Trans Natal Coal & Alfred McAlgine & $09 / 85$ & $11 / 85$ \\
\hline 4 & Union Corporation & Geduld Investments & 0776 & 1076 \\
\hline 5 & Anglo AM Ind. Corp & Bruynzeel Plywoods & 0876 & $11 / 76$ \\
\hline 6 & Volkskas & Bank OFS & $09 / 81$ & $11 / 81$ \\
\hline 7 & Anglo AM Properties & SOREC & $11 / 80$ & $02 / 81$ \\
\hline 8 & General Mining & Union Corporation & 1279 & $02 / 80$ \\
\hline 9 & Anglo AM Corp & Rand Selections & $01 / 77$ & $05 / 77$ \\
\hline 10 & Metkor Investments & Fowler Holdings & $04 / 78$ & $07 / 78$ \\
\hline 11 & Huletts Corp. & Tongaat & $01 / 82$ & $06 / 82$ \\
\hline 12 & East Driefontein & West Driefontein & $04 / 81$ & $06 / 81$ \\
\hline 13 & CNA Investments & Gallo Africa & $03 / 83$ & 08/83 \\
\hline 14 & Clydesdale & Apex & $12 / 85$ & $03 / 86$ \\
\hline 15 & Premier Milling & Propan & $08 / 77$ & 1077 \\
\hline 16 & Aberdare Cables & Scottish Cables & $06 / 85$ & $07 / 85$ \\
\hline 17 & Globe Engineering & Ships. \& Eng. Hlds. & $09 / 80$ & $12 / 80$ \\
\hline 18 & Score Food Holdings & Grand Bazaars & $07 / 86$ & $08 / 86$ \\
\hline 19 & Standard Bank Inv. & UDC Holdings & $05 / 78$ & $09 / 78$ \\
\hline 20 & Barlow Rand & Plascon-Evans & $04 / 87$ & $06 / 87$ \\
\hline 21 & Cons. Modderfontein & Springs Dagga Gold & $04 / 87$ & $06 / 87$ \\
\hline 22 & Rand Selections & S.A. Townships & $07 / 75$ & 1075 \\
\hline 23 & Phil Morkel Ltd. & Lewis Appliance Corp. & 0675 & $09 / 75$ \\
\hline 24 & Brick \& Clay & Eclipse Engineering & $04 / 75$ & $07 / 75$ \\
\hline 25 & Boland Bank & Voogdy Bank & $08 / 72$ & $02 / 73$ \\
\hline 26 & Kohler Brothers & Hayne \& Gibson Ltd. & $10 / 73$ & $12 / 73$ \\
\hline 27 & Vavasseur S.A. & Criterion Suzuki & $03 / 73$ & $08 / 73$ \\
\hline 28 & Anglo Tvl. Ind. & Nail \& Chain & $01 / 73$ & $05 / 73$ \\
\hline 29 & Barlow Rand & Rand Mines Holdings & $05 / 72$ & $09 \pi 2$ \\
\hline 30 & West Rand Inv. Trust & OFS Investment Trust & $02 / 72$ & $06 / 72$ \\
\hline
\end{tabular}

